\title{
Kritik Sosial dalam Lirik Lagu "Indonesia" Karya Rhoma Irama
}

\author{
Moh. Muzakka Mussaif \\ Fakultas Ilmu Budaya, Universitas Diponegoro \\ muzakkamoh@yahoo.co.id
}

\begin{abstract}
Rhoma Irama is a multi-talented artist who is very popular today. He has created many songs with many themes as well. One of the songs that voiced about nationalism, titled "Indonesia". However, in the lyrics of the song, he criticized the government because of social inequality that occurred in this rich and fertile country. Therefore, in this paper the author will uncover any social criticism that appears in the lyrics of the song "Indonesia" with the sociological approach to literature.

The results showed that in the song lyrics, Rhoma Irama made three criticisms to the government, namely (1) criticism of social class disparities, (2) criticism of the rampant corruption in bureaucracy, and (3) criticism of unfair government policies.
\end{abstract}

Keywords: Song lyrics, nationalism, social criticism.

\section{Intisari}

Rhoma Irama adalah seniman multitalenta yang sangat popular hingga kini. Ia telah menciptakan banyak lagu dengan banyak tema pula. Salah satu lagu yang menyuarakan tentang nasionalisme, berjudul "Indonesia". Namun, di dalam lirik lagu itu, ia melontarkan kritik kepada pemerintah karena adanya ketimpangan sosial yang terjadi di Negara yang kaya dan subur ini. Oleh karena itu, dalam tulisan ini penulis akan mengungkap kritik sosial apa saja yang muncul pada lirik lagu "Indonesia" dengan pendekatan sosiologi sastra.

Hasil penelitian menunjukkan bahwa dalam lirik lagu tersebut, Rhoma Irama melakukan tiga kritik kepada pemerintah, yaitu (1) kritik terhadap kesenjangan kelas sosial, (2) kritik terhadap maraknya korupsi dalam birokrasi, dan (3) kritik terhadap kebijakan pemerintah yang kurang adil.

Kata Kunci: Lirik lagu, nasionalisme, kritik sosial

\section{Pendahuluan}

Rhoma Irama dalam dunia seni sangat dikenal sebagai seniman multitalenta yang menghibur masa, baik melalui lagu-lagu yang diciptakan dan dinyanyikan maupun film yang dibuat dan 
dimainkannya. Dalam dunia musik ia dikenal sebagai musisi cerdas yang dapat mengawinkan musik Melayu dengan musik rock, pop, orchestra, dan India yang kemudian dikenal dengan musik dangdut. Sepanjang karier musiknya dengan Soneta Group sejak tahun 1970-an ia pun telah menciptakan banyak judul lagu dengan tema cinta, kemanusiaan, dan keagamaan,. Dalam dunia film, ia pun telah membuat dan memainkannya sendiri sebagai bintang pada 20an judul film. Dan, semua film yang dimainkannya pun dihiasi dengan musik dan lagu-lagu ciptaannya.

Dalam profil Rhoma Irama yang diunggah Wikipedia juga disebutkan bahwa berdasar pada data penjualan kaset, dan jumlah penonton film-film yang dibintanginya, penggemar Rhoma tidak kurang dari 15 juta atau $10 \%$ penduduk Indonesia. Rhoma Irama juga disebut sebagai salah satu seniman yang paling sukses dalam mengumpulkan masyarakat. Ia tidak hanya tampil di dalam negeri, tetapi juga di luar negeri seperti Malaysia, Singapura, Brunei, bahkan Amerika. Kesuksesan Rhoma dalam film tampak dalam data PT Perfin yang menyebutkan, bahwa semua film Rhoma cukup laku di pasaran. Bahkan sebelum selesai diproses, orang pun sudah membeli filmnya. Film Satria Bergitar misalnya, saat belum selesai dibuat sudah memperoleh tawaran pialang empat ratus juta rupiah. Yang sangat mengherankan, Rhoma tidak pernah mengambil uang dari hasil film yang dibuatnya. Beni Muharam, Produser PT Rhoma Film menyebutkan bahwa hasil film tersebut disumbangkan untuk membangun tempat ibadah dan perbaikan kampung-kampung serta untuk menyantuni anak yatim piatu dan beberapa kegiatan remaja. (https://id.wikipedia.org/wiki/Rhoma_Irama).

Terlepas dari kepopuleran sang Raja Dangdut, dalam tulisan ini penulis hanya akan mengkaji beberapa lirik lagu Rhoma Irama yang mengekpresikan kritik sosial. Sebab, di samping dikenal dengan sebutan seniman romantis dan relegius yang selalu menyuarakan pesan-pesan agama Islam, Rhoma Irama juga sangat tajam memberikan kritik sosial terhadap fenomena-fenomena sosial yang terjadi pada saat menciptakan lagu-lagunya. Kritik sosial yang dilontarkan Rhoma Irama dalam lirik lagu-lagunya kebanyakan bersifat nasionalisme dan atau religious. Hal itu tampak dalam beberapa lagunya seperti "Indonesia", "Hak Asasi", "Modern", "Rupiah", "Seni”, "Emansipasi Wanita", “Judi”, "Mirasantika”, "Euforia", dan masih banyak lagi yang lain. Untuk mengungkap secara mendalam gambaran kritik sosial 
yang diekpresikan dalam lirik lagu-lagunya diperlukan penelitian tersendiri. Namun, dalam tulisan ini, penulis hanya akan mengkaji beberapa lirik lagu Rhoma Irama sebagai pembuka wacana untuk melakukan penelitian mendalam terhadap karya-karya Rhoma Irama yang sangat banyak.

Yang dimaksud kritik sosial di sini adalah kritik yang terkait dengan masalah-masalah sosial atau kemasyarakatan yang muncul dalam karya sastra sebab sastra merupakan produk sosial. Sastra berada di tengah masyarakat yang muncul karena desakan-desakan emosional atau rasional dari masyarakat. Kegelisahan masyarakat menjadi kegelisahan para pengarangnya. Begitu pula harapan-harapan, dan penderitaan-penderitaan. Aspirasi mereka menjadi bagian pula dari pribadi pengarangnya sehingga melalui karyanya pengarang melakukan kritik terhadap apa yang terjadi di sekitarnya (Sumardjo, 1982:12). Karena karya sastra merupakan ekspresi atau ungkapan gejolak jiwa pengarang sedangkan pengarang juga anggota masyarakat yang berada pada kelas sosial tertentu dengan sistem sosial tertentu, maka hakikatnya karya sastra secara langsung maupun tidak menyampaikan kritik sosial. Pengarang yang peka terhadap kepincangan-kepincangan sosial seperti ketidakadilan, kemiskinan, kebodohan, politik, dan persoalan sosial lainnya, secara langsung maupun tidak langsung mengungkapkan kritik sosialnya melalui karyanya tentunya ia berharap agar pembaca menangkap pesan moral atau kritik sosial dalam karyanya. Hal ini sejalan dengan pendapat Budi Darma yang menyatakan bahwa kritik sosial merupakan salah satu ciri karya sastra. Karya sastra yang baik bisa banyak diwarnai kritik sosial. Namun baik buruknya karya sastra terletak pada unsur estetikanya, dan bukan semata-mata karena kritik sosialnya (1984: 66).

\section{Metode Penelitian}

Dalam tulisan pendek ini akan dikaji sebuah lirik lagu karya Rhoma Irama, yakni lirik lagu "Indonesia". Adapun fokus kajiannya adalah kritik sosial yang terdapat di dalam novel tersebut. Karena fokus kajiannya adalah kritik sosial maka perspektif kajian yang digunakan untuk menganalisis lagu tersebut adalah pendekatan sosiologi sastra, yaitu pendekatan yang menitikberatkan hubungan karya sastra dengan nilai-nilai sosial yang berlaku pada pengarang dan pembaca (Damono, 2010). Karena penelitian ini hanya fokus pada satu lirik lagu Rhoma 
Irama dan tidak melakukan penelitian terhadap pengarang dan pembaca, maka kategori penelitian ini adalah penelitian kepustakaan. Sebab, untuk mengungkap nilai-nilai karya sastra, terutama nilai kritik sosial dalam lirik lagu tersebut, tidak dilakukan wawancara langsung dengan pengarang dan pembaca. Berkenaan dengan hal itu, maka metode pengumpulan data dalam penelitian ini adalah studi pustaka, yaitu mengumpulkan data-data primer yang muncul dari lirik lagu "Indonesia" yang terkait dengan aspek-aspek sosial, khususnya kritik sosialnya.

Setelah data-data terkumpul, data-data tersebut dianalisis dengan cermat dengan menggunakan pendekatan sosiologi sastra yaitu pendekatan yang memandang karya sastra mempunyai hubungan erat dengan masyarakat dalam tataran realitas (Wellek dan Warren, 1990; Ratna, 2004; Damono, 2010). Sebab, karya sastra ditulis oleh pengarang yang juga anggota masyarakat. Hal-hal yang ditulis pengarang pun tidak sekadar mengangkat persoalan masyarakat, tetapi ia juga memberikan solusi ideal terhadap persoalan masyarakat dari sudut pandang pribadinya. Pun termasuk di dalamnya adalah pandangan kritisnya terhadap persoalan-persoalan yang terjadi dalam masyarakat. Salah satu bentuk reaksi pengarang terhadap fenomena yang terjadi di sekitarnya dapat mewujud dalam bentuk kritik sosial.

\section{Hasil dan Pembahasan}

Untuk menemukan makna yang utuh terhadap lirik lagu Rhoma Irama, terutama dalam kaitannya dengan kritik sosial yang diungkapkan pengarang, penulis akan menganalisis sebuah lirik lagu secara mendalam. Hal ini terkait dengan satuan struktur dari setiap lirik yang mengekspresikan kritik yang berbeda. Adapun dalam tulisan ini akan dianalisis sebuah lirik lagu yang bertemakan nasionalis karya Rhoma Irama yang berjudul "Indonesia".

\section{Kritik Sosial dalam Lirik Lagu "Indonesia"}

Lagu "Indonesia" diciptakan Rhoma Irama dan direkam Yukawi Record pada tahun 1980 dan dirilis pada tahun 1981. Lagu ini merupakan titel album Soneta Group volume kesebelas 
bersama empat judul lagu lainya. Untuk melihat secara utuh lirik lagu tersebut dan melihat wujud kritik sosialnya di bawah ini dikutip penuh liriknya.

\section{INDONESIA}

Hijau merimbuni daratannya

Biru lautan di sekelilingnya

Itulah negeri Indonesia

Negeri yang subur serta kaya raya

Seluruh harta kekayaan negara

Hanyalah untuk kemakmuran rakyatnya

Namun hatiku selalu bertanya-tanya

Mengapa kehidupan tidak merata

Yang kaya makin kaya....Yang miskin makin miskin

Yang kaya makin kaya....Yang miskin makin miskin

Negara bukan milik golongan

Dan juga bukan milik perorangan...

Dari itu jangan seenaknya

Memperkaya diri membabi buta...

Seluruh harta kekayaan negara

Hanyalah untuk kemakmuran rakyatnya

Namun hatiku selalu bertanya-tanya

Mengapa kehidupan tidak merata

Selama korupsi semakin menjadi-jadi

Jangan diharapkan adanya pemerataan

Masih banyak orang hidup dalam kemiskinan

Sementara ada yang hidupnya berlebihan

Jangan dibiarkan adanya jurang pemisah

Yang makin menganga antara miskin dan kaya

Bukankah cita-cita bangsa

Mencapai negeri makmur sentosa

Selama korupsi semakin menjadi-jadi

Jangan diharapkan adanya pemerataan

Hapuskan korupsi di segala birokrasi

Demi terciptanya kemakmuran yang merata

Bukankah cita-cita bangsa

Mencapai negeri makmur sentosa

Lirik yang dibuat puitis di atas sangat mudah dipahami pembaca. Rhoma Irama, sebagai anak bangsa, memuji penuh dengan rasa syukur pada Tuhan atas negeri Indonesia yang telah membesarkannya. Indonesia adalah negara kepulauan yang luas, subur, kaya dan indah. Indonesia kaya akan sumber daya alam yang cukup bahkan berlebih untuk menyejahterakan bangsa ini. Dengan kekayaan yang dimiliki negeri ini, seharusnya rakyat atau penduduknya makmur berkecukupan. Namun, begitu melihat fakta yang ada di tahun 1980-an ternyata 
banyak ketimpangan dan kesenjangan yang membelah dua kutub yang bertolak belakang, yakni kaya dan miskin /Yang kaya makin kaya// yang miskin makin miskin/. Itulah pertanyaan yang diulang-ulang. Aku lirik merasa heran mengapa kemakmuran bangsa ini tidak merata. Inilah awal kritik sosial yang diteriakkan Rhoma Irama dalam lirik lagu "Indonesia" dengan nada ironis yang cenderung sinis.

Pertanyaan retoris semacam itu bukan hal yang mengada-ada jika dikaitkan saat diciptakannya lagu ini. Era 1980-an adalah era rezim orde baru yang amat kuat di bawah Presiden Soeharto yang memimpin negeri ini sejak 1966. Rhoma Irama melalui Aku lirik mempertanyakan kesenjangan antara si kaya dan si miskin. Karena berdasarkan pemahamannya terhadap konstitusi (Pancasila dan UUD 1945) bahwa seluruh kekayaan negara dikelola untuk kemakmuran bangsa, bukan untuk golongan tertentu maupun orangorang tertentu. Menurutnya, Negara itu bukan milik golongan dan atau perseorangan, tetapi milik seluruh bangsa. Jadi, jika Negara hanya dikuasai golongan dan atau individu tertentu itu adalah bentuk penyimpangan terhadap konstitusi Negara.

Pertanyaan terhadap kesenjangan ekonomi itu tidak berhenti dalam nada ironis dan sinis, tetapi dilanjutkan dengan dengan sikap kritis terhadap rezim Soeharto. Dengan nada tegas Rhoma Irama melontarkan lirik /Negara bukan milik golongan/ dan juga bukan milik per orangan/ dari itu jangan seenaknya/ memperkaya diri membabi buta/. Dengan kritik tajam, ia melontarkan tentang kedudukan Negara yang sesungguhnya. Dengan sangat tegas ia mengingatkan rezim penguasa untuk tidak mengambil kekayaan Negara secara golongan maupun per orangan untuk memperkaya diri dan kelompoknya.

Bila dikaitkan dengan politik orde baru, tahun 1977 hanya ada tiga partai yang menjadi kontestan Pemilu, yakni PPP, Golkar, dan PDI. Golkar dengan dukungan militer menguasai panggung politik dengan mengusung Soeharto sebagai Presiden RI. Adapun PPP yang disebut sebagai partainya umat Islam jumlah pendukungnya kurang signifikan jika dibanding Golkar. Apalagi PDI yang menjadi partainya kaum marhaenis sangat kecil jika dibandingkan Golkar. Di sinilah Presiden dan Golkar dapat mengatur Negara ini dengan sepenuhnya. Karena lirik lagu ini ditulis belasan tahun dari kepemimpinan Soeharto dan Golkar sebagai partai yang sangat kuat, maka kekuatan eksekutif dan legislatif menyatu kuat dan tak tertandingi. Kekuatan itulah yang menimbulkan kutub kaya dan miskin serta berkuasa dan dikuasai. Munculnya kesenjangan itu ditengarai dengan maraknya korupsi dalam berbagai birokrasi. Kedua hal itu sangat terkait dengan kebijakan pemerintah yang dianggap menyimpang terhadap tujuan Negara, yakni menciptakan masyarakat Indonesia yang sejahtera, adil, dan makmur sebagaimana yang termaktub dalam Pancasila dan UUD 1945.

Berdasarkan lirik lagu"Indonesia" di atas ada beberapa kritik sosial yang dilontarkan Rhoma Irama sebagai pencipta lagu yang ditujukan pada pemerintah dengan kebijakan- 
kebijakannya.. Ada tiga kritik sosial yang menonjol dalam lirik lagu tersebut, yaitu (1) kritik terhadap kesenjangan kelas sosial, (2) kritik terhadap maraknya korupsi di berbagai birokrasi dan (3) kritik terhadap kebijakan pemerintah yang kurang adil. Untuk memperjelas tiga kritik sosial yang muncul dalam lirik lagu tersebut akan diuraikan satu per satu.

\section{Kritik terhadap Kesenjangan Kelas Sosial}

Kritik sosial yang dilontarkan Rhoma dalam lirik lagu "Indonesia" adalah munculnya kesenjangan sosial yang dominan, yakni munculnya dua kelas yang beroposisi biner, yakni "golongan orang kaya" dan "golongan orang miskin". Mengapa hal itu bisa terjadi di Negara yang subur dan kaya sumber daya alam ini? Inilah yang dipertanyakan dan disorot tajam dalam lirik lagu tersebut.

Kondisi demikian menjadi kian dipertanyakan ketika muncul golongan kaya kian bertambah kaya dan golongan miskin semakin banyak dan bertambah miskin. Kritik tajam dan keras itu dilontarkan dengan pengulangan bagian lirik yang menyebutkan /yang kaya makin kaya//yang miskin makin miskin/. Aku lirik mempertanyakan hal demikian ini cukup logis karena melihat kekayaan Negara yang melimpah. Hal demikian ini seharusnya tidak terjadi kalau pengelolaan sumberdaya alam dan sumberdaya manusia dilakukan secara baik dan benar mengacu pada tujuan nasional yang sangat jelas yakni menciptakan masyarakat yang adil dan makmur. Dengan hadirnya golongan kaya yang kian kaya dan golongan miskin yang kian miskin ini berarti prinsip keadilan dan kemakmuran bersama itu tidak dilaksanakan dengan baik, bahkan cenderung ditentang oleh rezim,

Ungkapan lirik lagu "Indonesia" itu memang sangat sesuai dengan kondisi zaman lagu itu diciptakan. Dengan kekuasaannya yang sempurna rezim Soeharto menjadi sangat kuat dan mendominasi seluruh aspek sosial, ekonomi, politik, birokrasi, dan sebagainya. Dengan kokohnya rezim ini maka siapapun pendukung rezim akan mendapatkan kesempatan untuk mendapatkan fasilitas-fasilitas yang lebih dari yang lain. Sebaliknya, golongan atau kelompok yang berseberangan dengan rezim akan mendapatkan hambatan-hambatan, termasuk fasilitasfasilitas Negara. Dari lirik lagu ini tampaklah bahwa sang pencipta adalah orang yang berseberangan dengan rezim kekuasaan.

Jika dikaitkan dengan penciptanya, memang Rhoma Irama di tahun 1970-an hingga 1980-an berseberangan dengan Golkar sebagai pengusung Soeharto. Di era tahun tersebut ia malah mendukung kuat Partai Persatuan Pembangunan (PPP) yang berasas Islam. Dengan pandangan-pandangan kritisnya, Rhoma juga digandeng PPP untuk menjadi juru kampanye di 
dua musim pemilu (1981, 1986). Dengan berseberangan dengan rezim itulah, kemudian Rhoma juga pernah dicekal tidak boleh masuk TVRI.

\section{Kritik Terhadap Maraknya Korupsi di Berbagai Birokrasi}

Di samping melakukan kritik sosial terhadap munculnya kesenjangan sosial (kayamiskin) di negeri ini, Rhoma Irama melalui Aku lirik juga menegaskan bahwa perbuatan melawan hukum, yakni korupsi bermunculan dalam semua tatanan birokrasi. Dari maraknya perbuatan korupsi inilah, aparatur pemerintah atau Negara dapat memperkaya diri dan atau dengan kelompoknya. Sementara, Negara dan rakyat jelata yang menjadi sasaran korupsi menjadi miskin dan menderita.

Wujud perbuatan korupsi di sini cukup beragam, mulai dari mengambil keuntungan dari uang Negara, uang suap-menyuap, sampai pada pungutan liar (pungli). Perbuatan melawan hukum yang demikian itu banyak dilakukan oleh oknum-oknum aparatur pemerintah (Negara) pada rezim Soeharto saat lirik lagu diciptakan (1980-an). Aku lirik menegaskan bahwa perbuatan korupsi yang demikian itu menjadikan rakyat jelata menjadi semakin miskin dan susah hidupnya, sementara aparatur Negara dapat memperkaya diri karena mengambil uang Negara dan uang rakyat. Di sinilah Aku lirik tidak hanya melakukan kritik terhadap pemerintah, tetapi dengan tegas mendesak kepada pemerintah untuk memberantas beragam bentuk korupsi yang sudah membudaya di negeri ini. Hal itu tertera dengan sangat jelas dalam kutipan lirik lagu "Indonesia" di atas. Jika korupsi makin marak dan tak terkendali maka tidak akan terwujud masyarakat adil makmur. Karena itu, solusinya adalah harus menghapus segala korupsi yang terjadi dalam berbagai tingkatan birokrasi dari pusat sampai daerah.

Baris-baris lirik di atas menegaskan bahwa Aku lirik mengingatkan sekaligus mendesak kepada pemerintah untuk menghapuskan berbagai bentuk korupsi di berbagai lini. Sebab, tujuan pembangunan nasional yakni menciptakan kemakmuran yang merata. Semua itu tidak terwujud tanpa adanya langkah konkret pemerintah yang harus berlaku adil terhadap semua warganya. 


\section{Kritik Terhadap Kebijakan Pemerintah yang Kurang Adil}

Kritik terhadap kebijakan pemerintah yang kurang adil dalam lirik lagu "Indonesia" ini adalah ruh lagu ini yang seutuhnya. Sebab, munculnya kesenjangan sosial (yang kaya makin kaya - yang miskin makin miskin) dan munculnya budaya korupsi di Indonesia sangat terkait dengan kebijakan pemerintah yang kurang adil dan tidak berpihak pada rakyatnya.

Negara Republik Indonesia menganut sistem demokrasi, yang disepakati pendirinya dengan demokrasi Pancasila. Sistem ini sangat jelas, mengatur bahwa kekuasaan Negara berada di tangan rakyat. Segala kekayaan Negara diatur untuk mencapai kemakmuran rakyatnya. Namun, secara nyata di era rezim Soeharto tampak banyak penyimpangan terhadap sistem demokrasi Pancasila. Yakni kebijakannya lebih berpihak pada individu-individu tertentu dan golongannya. Di sinilah Aku lirik mengkritisi bahwa kebijakan pemerintah dalam mengelola asset-aset bangsa sangat tidak adil. Aku lirik dalam lirik lagu "Indonesia" seakan berteriak lantang dengan melontarkan kata-kata yang bernada emosional penuh kemarahan. Aku lirik memperingatkan pemerintah dengan kutipan lirik lagunya bahwa Negara itu bukan milik golongan tertentu, bukan pula milik individu-individu. Karena bukan milik golongan dan individu itu, maka golongan atau individu dilarang keras mengambil kekayaan Negara dengan cara sesukanya.

Dari larik-larik lirik lagu Indonesia di atas tampak jelas dan tegas, bahwa Rhoma Irama tidak hanya melontarkan kritik sosial pada pemerintah, tetapi memprotes keras pemerintah terhadap penyimpangan yang ada. Ia menilai kebijakan pemerintah tidak benar, karena tidak bertolak pada konsitusi yang ada. Intinya Rhoma menganggap bahwa kebijakan pemerintah sangat berpihak pada golongan tertentu sehingga dinilai tidak adil karena kebijakannya tidak berpihak pada rakyatnya.

\section{Simpulan}

Dari uraian di atas tampak jelas bahwa kritik sosial, khususnya kritik terhadap pemerintah dan kebijakannya dapat dilakukan dengan berbagai cara, salah satunya dapat dilakukan melalui aktivitas kultural. Rhoma Irama sebagai musisi dan pencipta lagu dapat melakukan kritik tajam kepada pemerintah melalui lirik lagu "Indonesia". Dengan sikap nasionalismenya, 
Rhoma Irama yang menilai bahwa Negara Indonesia yang kaya akan sumber daya alam dan manusia itu jika diatur dengan benar dapat memakmurkan bangsanya. Namun, karena dalam realitas itu terjadi ketimpangan dan penyimpangan dalam pengelolaannya, maka semakin jauh untuk memuwujudkan cita-cita bangsa, yakni menciptakan masyarakat yang adil dan makmur. Dari analisis terhadap lirik lagu di atas, melalui Aku lirik, melakukan tiga kritik sosial yang utama, yakni kritik terhadap kesenjangan kelas sosial, kritik terhadap maraknya praktik korupsi, dan kritik terhadap ketidakadilan kebijakan pemerintah.

\section{Daftar Pustaka}

Damono, Sapardi Djoko. 2010. Sosiologi Sastra: Pengantar Ringkas (edisi baru). Ciputat: Editum.

Darma, Budi. 1984. Sejumlah Esei Sastra. Jakarta: Karya Unipress.

"Profil Rhoma Irama” dalam (https://id.wikipedia.org/wiki/Rhoma_Irama).

Ratna, Nyoman Kutha. 2004. Teori, Metode, dan Teknik Penelitian Sastra. Yogyakarta: Pustaka Pelajar.

Soemardjo, Jacob. 1982. Masyarakat dan Sastra Indonesia. Bandung: Nur Cahaya.

Wellek, Rene dan Austin Warren. 1990. Teori Kesusastraan. (diindonesiakan oleh Melani Budianta). Jakarta: Gramedia. 